\title{
A comparative Geological, Tectonic and Geomorphological assessment of the Charlotte, Regent and Madina Landslides, Western Areas, Sierra Leone
}

\author{
Yusuf Alhaji Lahai ( $\sim$ lahaialhajiyusuf@yahoo.com ) \\ University of Sierra Leone \\ Kelvin F. E. Anderson \\ National Minerals Agency (NMA) \\ Yaguba Jalloh \\ University of Sierra Leone \\ Ibrahim Rogers \\ Sierra Rutile company LTD \\ Mohamed Kamara \\ National Minerals Agency (NMA)
}

\section{Research}

Keywords: Geology; geomorphological characteristics; mapping; petrological characterization; tectonics

Posted Date: March 5th, 2020

DOI: https://doi.org/10.21203/rs.3.rs-16192/v1

License: (c) (1) This work is licensed under a Creative Commons Attribution 4.0 International License.

Read Full License

Version of Record: A version of this preprint was published at Geoenvironmental Disasters on July 19th, 2021. See the published version at https://doi.org/10.1186/s40677-021-00187-x. 


\section{Abstract}

This work focused on three landslide events that have attracted significant public concern due to the associated calamities. The slides have been analyzed for their geology, tectonics and geomorphological (GTG) characteristics. In addition, an understanding of the link between GTG characteristics and the landslide events was established.

To achieve this, field surveys were conducted, particularly for the Charlotte landslide, where identification of geological structures was perturbed by the obliteration of vegetation and sediment accumulations on relatively planar sections of the landslide area. GIS and remote sensing techniques enhanced mapping and determination of landslide characteristics, and laboratory analyses on rock samples provided the petrological characterization of the landslides.

Results indicated change in rock composition (gabbro), variable geomorphological characteristics and the nature/pattern and density of discontinuities; these factors, to a large extent, determined the nature and magnitude of the rainfall-triggered landslides. Charlotte lithology slightly differs from and recorded higher Silica (Si) and Aluminum (Al) and lower iron (Fe) than rocks of Regent and Madina landslides. Study also revealed only tenuous correlation between rock composition and weathering depth. The slope angles for the landslides' main scarps (depletion zone) are steep ( $>45$ degree) with altitudes $\approx 270 \mathrm{~m}$, $470 \mathrm{~m}$ and $200 \mathrm{~m}$ above sea level for Charlotte, Regent and Madina respectively. Additionally, the area and length of the landslides have relatively high variance $(C V=1)$ and the variance of their run-outs as well is high ( $C V>1)$. Finally, information derived from this work can be useful to understand the spatial variation in landslide characteristics and the development of a susceptibility map.

\subsection{Introduction}

Mountainous areas around the globe have the propensity to be affected by landslides, leading to fatalities and damage to property (Dai et al., 2002). Records show that 200 landslides claimed more than 500 lives in the Himalayas (Kumar et al., 2014). Landslides account for 20-25 fatalities and an estimated US\$ 1-2 billion annually in the United States of America (Schuster et al., 1986); and in Italy, a minimum of 263 lives were lost from mass movement in a nine years period (1990-1999) (Guzzetti 2000).

The hilly and mountainous central part of the Freetown Layered Complex, has documented more landslide events (FCC, 2014), and caused colossal losses (UNDP\&EPA, 2017) than any other place within the Layered Complex. One such incident was the Regent landslide which affected the Sugarloaf Mountain, and claimed more lives than anywhere in the world in 2017 (Redshaw et al., 2019). This slide like other landslide events is influenced by multitude of factors. The past and present landslides were produced under certain geologic, geomorphologic and hydrologic conditions, which may reoccur and as such their characteristics should be studied to better define and understand their relationships with other 
landslide incidents. This knowledge will help the authorities to make informed decisions in mitigating such occurrences.

Studies by few researchers such as Delmonaco et al, (2006), Chigira, 2006; Nakano et al., (2015); Vipin et al., (2018); Borrelli et al., (2018); and Lupiano et al., (2018), have shown that landslide events are linked to the geology (rock types) and geomorphology. Nugraha et al. (2015) mentioned that geomorphometric characteristics have the most significant relationship with landslide distribution. Research has also revealed that landslide occurrence can be closely connected to anthropogenic factors (e.g. deforestation, slope undercutting and construction) (Skilodimous et al., 2018 and Cui et al., 2019), and geological structures (Cerri et al., 2017 ;).

Despite the socio-economic and geomorphologic impacts associated with landslides (Ngeku and Mathu, 1999; Ngeku et al., 2004 and Jacobs et al., 2016), which are expected to increase with global climate change (Nugraha et al., 2015), studies are still rare in the Africa continent (Maes et al., 2017), considering scientific literature (e.g.; Knapen et al., 2006; Van Den et al., 2009; Che et al., 2011; Broothaerts et al., 2012; Maki Mateso and Dewitte, 2014; and Jacobs et al., 2016). Most of the studies in literature have been done elsewhere in other continents, with their own unique terrain conditions.

The situation is even worst in Sierra Leone, which has very limited and restricted scientific landslide studies (e.g. Thomas, 1983, 1994 \& 1998; Cui et al., 2019, Redshaw et al, 2019; and Lahai and Lahai 2019), amidst a surge of landslides in its capital city. This is also supported by the exclusion of localized landslide crises in the International Emergency Database (EM-DAT) and the Global Disaster Identifier (GLIDE), despite its serious impacts; indicating a dearth in landslide knowledge in this part of the world. In effect, excluding work by Thomas $(1983,1994$ \& 1998) which concentrates only on the central highlands, records show that, the only studies done are by Cui et al. (2019); Redshaw et al. (2019) and Lahai and Lahai, (2019), and these are focused on the Regent landslide. It is therefore clear that, the influences of geology, geomorphology and geological structures on landslide occurrences have neither been studied nor well defined in the country (landslide characteristic data remain poor or inexistent). Also, no attempt has been made to contrast these factors for different landslides in order to establish their spatial characteristics in the area represented by the topographic map in Fig. 1. This work therefore provides the impetus for fulfilling this gap, through the conduction of a systematic characterization of the slopes.

This study considered three major, spatially distributed landslides at Charlotte, Regent and Madina in the western area rural district. Extensive documentary analysis, field surveys, remote sensing techniques (earth imagery -accessed in 2019 and drone images), and laboratory analysis were undertaken. These generated information on the landslides' occurrence times, activities, and their spatial variation in geology, tectonics (geological structures) and geomorphology.

A comprehensive documentation of the geologic, tectonic and geomorphologic (GTG) characteristics was accomplished by this work, from which relevant scientific data, necessary for developing landslide susceptibility map of the study area could be obtained. Detailed, systematic and localized data generated from the research could be fundamental for policy makers and development practitioners, and would be 
shared with the Office of the National Security (ONS) and other relevant institutions/departments for consideration during disaster related Policy formulation. This work will provide the platform for further studies necessary for Landslide Risk Management (LRM).

\subsection{Description Of Landslide Areas}

The three major landslides are situated in the north-western part of Freetown. Specifically, they are found at Charlotte $\left(8^{0} 42 \mathrm{~N}, 13^{0} 23^{\prime} \mathrm{W}\right)$, Regent $\left(8^{0} 39^{\prime} \mathrm{N}, 13^{0} 21^{\prime} \mathrm{W}\right)$ and Madina $\left(8^{0} 42 \mathrm{~N}, 13^{0} 21 \mathrm{~W}\right)$, and their locations are indicated on a topographic map of scale 1:40000, covering an area of approximately $57 \mathrm{~km}^{2}$ obtained from the Directorate of Geological Survey at the National Minerals Agency (NMA), in Sierra Leone (Fig. 1 below). This map forms part of zone three (3) of the topographic map of Freetown and sheet two (2) of the western area of Sierra Leone.

Insert Figure 1 here.

The landslides occur on land surfaces belonging to the 4th geomorphological class of Sierra Leone, comprising hills of basic and ultrabasic rocks. The hills and plains have given rise to high topography and steep slopes with altitudes ranging from $181 \mathrm{~m}$ to $901 \mathrm{~m}$ above mean sea level. The southward extended hills at Regent are once-protected forest highlands, but are now threatened by encroachment due to uncontrolled urban developments, making it subject to continuous slope instability. This instability is further exacerbated by stone mining as in the case of Madina slopes, sediment piling by United Nations Office for Project Services (UNOPS) along Babadorie valley and subsequent slope collapse caused by stream erosion, resulting in the current shape of the landscapes (denuded hills and wider valleys).

Climatologically, the landslide areas are similar, and they experience tropical and humid type of climate that is controlled largely by the tropical air mass affecting the entire sub-region as a whole. Analysis of rainfall data obtained from the country's Meteorological Agency indicates higher amount of precipitation (100 mm to $1200 \mathrm{~mm}$ ) from July to September: the months most of the landslides occur. This can be attributed to the prevalence of heavy down pour of rains in these months, reaching a height of $539.9 \mathrm{~mm}$ on average according to BBC, (2017). The rainfall condition that caused the Charlotte landslide recorded beyond $1000 \mathrm{~mm}$ over a period of five days, and $400 \mathrm{~mm}$ in the 24 hours preceding the failure (Redshaw et al., 2019). $1040 \mathrm{~mm}$ of rain was recorded for six weeks (1 July - 14 August, 2017)-three times more than expected for the same period during a typical rainy season, and this condition triggered the Regent landslide (Redshaw et al., 2019).

The underlying geology of the three landslides is part of the Freetown Layered Complex, which is gabbroic and made up of rocks ranging from Anorthosite (top of a unit) to Dunite (bottom of a unit). Studies by Chalokwu et al., 1995; Chalokwu, 2001; Callegaro et al., 2017, mentioned that the complex represented part of the voluminous Central Atlantic Magmatic Province (CAMP) which intruded the West African Craton during the Early Jurassic c. 200 Ma. Field works confirmed typical orientation of layers in 
the WNW-ESW direction with a steep dip in the direction of NNE. The joints and fractures present on rock surfaces are deeply weathered (Redshaw et al., 2019).

The steep slopes, heavy rainfall, shallow soils and intense weathering in the Freetown Layered Complex make it susceptible to slope failures along planes of weakness, generating landslides and associated flooding. Unlike others, there are observable old scars or gully erosions around the Regent landslide main body thought to be associated with lineaments (UNDP \& EPA, 2017). Identification of historic and ancient landslides is recognized through aerial photographs and field studies (World Bank, 2017-unpublished observations), which were initially mapped by Thomas in the 1970s and 1980s (Thomas, 1998); and later modified by the British Geological Survey (BGS). Madina landslide is not captured in that map.

\section{0 Methods}

The field work included mapping of the three landslides. These were aided with the use of Google earth and drone images. Drone images were obtained from the aerial survey conducted by Track Your Build (TYB, 2019), Sierra Leone Limited, only for the Madina Landslide, during a quick assessment by the ONSTechnical Pillar team.

The landslides were initially identified by the residents of the respective communities, and their point coordinates determined using a Global Positioning System (GPS) during the surveys. Descriptions and classification were done in accordance with Cruden and Varnes (1996) and Hungr et al (2001). The area and perimeter were obtained using Google Earth and drone images and validated in the field. Information on landslides' occurrence times and activities was derived from various local and international analysis reports and interviews with local people. Other landslide characteristics measured include; slide volume, slide length, slide width and total run-out.

The landslide bodies were mapped from crown to toe of rupture applying similar approach presented by Aleotti and Chowdhury (1999) and Igwe and Una (2019), with focus on geology, tectonic evidence and geomorphic elements. Rock analyses involved hand sample description, thin section and X-Ray Fluorescence (XRF) analysis for textural features, mineralogical composition and the percentages of elements in rock samples from the landslide areas. This Petrological characterization formed the basis for assessing the underlying lithology of the various slide areas. Additionally, weathering pattern and depth, boulder dimension, soil types and compositions were determined.

Tracing of geological structures (cracks, joints and faults) was possible through field structural mapping. The locations and attitude (strike, dip angle and dip directions) of these lineaments/discontinuities on the landslide main bodies and adjacent places were determined and recorded. They were compared with the regional lineament distribution map of Freetown, produced by using automatic alignment identification tools from data provided by Cynthia Linero Molina and the BGS. Other features recorded included layering and dip of rocks. 
In order to understand the susceptibility of the land surfaces affected by the landslides, slope angles, slope aspects and elevations were determined using the Silva-type compass, contour maps and Global Positioning System (GPS). 2D Orthomosaic analysis generated slope information on Madina landslide, which was used to validate slope gradient obtained by the method above. Further and improved understanding of the morphology of the landslides and their topographic locations were achieved by making schematic cross-sections of each landslide body and with the aid of a Digital Elevation Model (DEM) of the area represented by a topographic map in Fig. 1.The DEM was created by digitizing the $20 \mathrm{~m}$ contour lines of the map, and maintaining a spatial resolution of $33 \mathrm{~m}$. The relationship between the slides and the land surfaces was established by plotting their GPS coordinates on the DEM.

\subsection{Results And Discussions}

\subsection{Inventory of the landslide events}

Information on landslide inventory includes; landslide location, occurrence time, length, area, perimeter, typology, and activity. Figure 1 represents the spatial distribution of the landslides (landslide locations) and the others summarized in Table 1 below. Included in the table are other specific landslide attributes and statistics of quantitative parameters/data. Landslide areas and lengths have Coefficient of Variance $(\mathrm{CV})$ that is equal to one $(\mathrm{CV}=1)$, greater than one $(\mathrm{CV}>1)$ for their run-outs, and there is low or no variance for the landslide perimeters $(\mathrm{CV}<1)$. 
Table 1

Landslide inventory

(Source: Documentary and field data, 2019)

\begin{tabular}{|c|c|c|c|c|c|c|}
\hline & $\begin{array}{l}\text { Charlotte } \\
\text { landslide } \\
(\mathrm{CH})\end{array}$ & $\begin{array}{l}\text { Regent landslide } \\
\text { (RT) }\end{array}$ & $\begin{array}{l}\text { Madina } \\
\text { landslide (MD) }\end{array}$ & Average & St. Dev. & CV \\
\hline Date & $\begin{array}{l}\text { 10th August, } \\
1945\end{array}$ & 14th August, 2017 & $\begin{array}{l}\text { 2nd August, } \\
2019\end{array}$ & & & \\
\hline Time & 4:00 PM & 6:30 AM & 9:30 PM & & & \\
\hline Length (m) & 328.92 & 370.91 & 71.8 & 257.2 & 161.9 & 1 \\
\hline $\begin{array}{l}\text { Perimeter } \\
\text { (m) }\end{array}$ & 822.92 & $1,427.73$ & 649.81 & 966.8 & 408.4 & 0 \\
\hline Area $\left(\mathrm{m}^{2}\right)$ & $27,749.62$ & $99,759.29$ & $19,053.02$ & 48854.0 & 44299.2 & 1 \\
\hline Topology & $\begin{array}{l}\text { Rock fall \& } \\
\text { Rotational }\end{array}$ & $\begin{array}{l}\text { Translational } \\
\text { \&wedge sliding }\end{array}$ & Translational & - & - & \\
\hline Activity & In active & Active & Active & - & - & \\
\hline $\begin{array}{l}\text { Slide } \\
\text { volume } \\
\left(\mathrm{m}^{3}\right)\end{array}$ & $138,748.40$ & 300,000 & 18,575 & 152441.1 & 141211.3 & 1 \\
\hline $\begin{array}{l}\text { Total- } \\
\text { out(m) }\end{array}$ & 400 & 6000 & 148 & 2182.7 & 3308.3 & 2 \\
\hline
\end{tabular}

\subsection{Landslide characteristics}

\subsubsection{Geology}

The geology in this context includes the rock types, weathered profiles, and landslide debris comprising soil, gravel and boulders.

Two rocks of the Freetown Layered Complex underlie the landslides. They are norite and olivine gabbro. The Norite is texturally variable (mineral grains are coarse) from the olivine gabbro (medium-grained rock) and are all weakly foliated. Norite is the dominant rock type present in the Charlotte landslide, and it consists of plagioclase (62.5\%), augite (an ortho pyroxene that showed parallel extinction and constituted $95 \%$ of the pyroxenes present) $(28.5 \%)$, clinopyroxene (1.5\%), opaque minerals that are essentially iron oxides (5\%), and others (2.5\%)-Figure 2. The rock mineral grains are subhedral and form a steep layering of 64 degree in the NNE direction. Regent and Madina landslides have olivine gabbro as their dominant rock type. Minerals present include: plagioclase (40\%), Olivine (30\%), pyroxene (clinopyroxene evident by an inclined/oblique extinction) (20\%), opaque minerals (4\%) and others (6\%). Dolerite (diabase) which is texturally and mineralogically distinct, is well exposed at the Regent landslide, and occurs as discordant 
bodies within the host rock (Fig. 8). The pyroxenes and olivine are subhedral in the Regent landslide as well (Fig. 2). Madina landslide sample shows anhedral olivine grains in the rock sample. The rock layers dip between 20 and 40 degrees in southwest direction.

Insert Figure 2 here.

XRF results show relatively higher iron content, and lower silica and Aluminum (Al) for Regent and Madina landslides in contrast with the Charlotte landslide, ascertaining the abundance of specific mineral rich element and the type and abundance of opaque minerals (Table 2).

Table 2

Hand held-XRF Results obtained from rock samples of the three slides

\begin{tabular}{|c|c|c|c|}
\hline \multirow[t]{3}{*}{ ELEMENTS } & \multicolumn{3}{|c|}{ X-RAY FLUORESCENCE READINGS } \\
\hline & \multicolumn{3}{|l|}{ Sample ID } \\
\hline & $\begin{array}{l}\text { Charlotte landslide } \\
\text { (CH) }\end{array}$ & $\begin{array}{l}\text { Regent landslide } \\
\text { (RT) }\end{array}$ & $\begin{array}{l}\text { Madina landslide } \\
\text { (MD) }\end{array}$ \\
\hline Unit & Ppm & Ppm & Ppm \\
\hline LE & $45.67 \%$ & $46.50 \%$ & $42.89 \%$ \\
\hline Si & $23.08 \%$ & $22.80 \%$ & $22.64 \%$ \\
\hline $\mathrm{Ca}$ & $15.27 \%$ & $16.47 \%$ & $19.58 \%$ \\
\hline Al & $11.83 \%$ & $9.54 \%$ & $8.15 \%$ \\
\hline $\mathrm{Fe}$ & $2.40 \%$ & $3.31 \%$ & $4.57 \%$ \\
\hline $\mathrm{Mg}$ & $0.75 \%$ & $0.97 \%$ & $1.57 \%$ \\
\hline $\begin{array}{l}\text { Others (Ti, Mn, Sr,V, Ni,Cu, Zn, } \\
\text { Th,Nb, Zr) }\end{array}$ & $1.00 \%$ & $0.41 \%$ & $0.60 \%$ \\
\hline Rock type & Norite & Olivine gabbro & Olivine gabbro \\
\hline
\end{tabular}

The weathering profiles at the ridge tops of the landslides are estimated at 3.5, 12 and 1.3 meters for Charlotte, Regent and Madina landslides respectively. Determinable weathering profile also extends to their flanks. Chalotte east flank adjacent second bench is $\approx 18 \mathrm{~m}$ thicker, Regent east flank has a relatively thin regolith ranging from 1 to 5 meters, while Madina shows thicker weathering at both landslide flanks than the crown (head wall) (Fig. 2-center )

Insert Figure 3 here.

The soil type covering Charlotte, Regent and Madina landslide areas is the same (very gravelly ferralitic soils with shallow soils on moderate to high relief hills formed from basic and ultrabasic rocks (Fig. 3) 
formed directly from the chemical alteration of the parent gabbroic rock types. Field logging of soil samples at Chalotte and Madina landslides revealed similar result to the soil classification conducted on bulk samples collected from the Regent Landslide debris (matrix, excluding boulders and cobbles) and analyzed at BGS laboratories as reported by Redshaw et al., 2019 (31\% gravel, 36\% sand, 19\% silt and $14 \%$ clay). The fines (clay and silt) content slightly exceeds that of the gravel, and this situation increases for the Charlotte landslide with its lithology having the highest silica and aluminum content (Table 2). Clays at Regent landslide are much more visible in joints, fractures etc, as a result of chemical weathering and breakdown of plagioclase feldspars, to form clay minerals (secondary minerals). The thickness of soil and rock weathering profiles at the three sites are locally affected by the following; bedrock texture, geochemistry, mechanical discontinuities (joints, faults and shears) and the degree/depth of laterization and saprolite development (Redshaw et al., 2019), and is much pronounced in the Regent landslide.

\subsubsection{Tectonics (Geological structures)}

Discontinuities and lineaments are used interchangeably in this study to describe faults, cracks and joints. They are linear structures that represent mirror image of subsurface condition (O'Leary et al., 1976).

Charlotte landslide discontinuities are not clearly exposed due to the re-colonialization of vegetation and sediment accumulation on relatively planar sections of the landslide area. However, springs/creeks in open joint, running from upslope to down slope observed during field surveys are indicative of subsurface discontinuities, and this is supported by similar studies done by Lattman and Parizek (1974); Sander et al., (2005); Jha et al. (2007); and Al-Nahmi et al., (2016). They run closer to both east and west flanks that formed the slide margins. Attached to these main stream channels are minor network (trellised) of open joints with water seepages during the rains. There general strike direction (SW-NE) corresponds to the landslide slope aspect.

Regent landslide consists of several discontinuities (dense lineaments) on the main scarp. The open joints have variable dips (from 15 to 40 degree NNE); with orientation parallel to the slope face, corresponding to the weathered sheet joints described by Redshaw et al., 2019. The marked change observed in dip and joint patterns differentiates the upper from the lower main scarp. Water seepages coming out from the depletion zone, indicating the occurrence of open joints/ fractures were observed during field exercises. The second landslide surface of the Regent landslide shows weathered NNE joint/fault zone with dip between 45-50 degrees. There is a clearly visible new fracture at the adjacent main scarp (unaffected part of the slope of the west flank), extending from top to sub-parallel bench at the time of last survey (6th September, 2019). It is most likely that the next sliding plane will occur along it (Figure 4b).

Insert Figure 4 here.

Unlike the other landslide bodies, Lineaments/discontinuities are absent on the main slide surface of Madina landslide (Fig. 4C). The landslide has had consistent failures along planes of weaknesses i.e. 
lateral extension of the head wall/flanks, and has caused the formation of shallow cracks on adjacent surfaces. A typical example is the WNW-ESE cracks (approx. $7 \mathrm{~m}$ apart) on the hill slope, running from below the structure above, with geographic coordinates in latitude and longitude recorded as $8^{0} 44^{\prime} \mathrm{N}$ and $13^{0} 23^{\prime} \mathrm{W}$, extending to the slide area. Evidence of these cracks is found on the floor of the structure above as observed in Fig. 5. They are most likely to form the next temporary sliding plane for any subsequent earth movements. They disappear on the slide surface after the downslope movements of debris, indicating that they are not deep-seated discontinuity in contrast with the others (joints and cracks are confined within the weathered zone).

Further field surveys away from the main body of Madina landslide, but in close proximity with it, uncovered several surface discontinuities at hill tops evident by spring seepages; adjacent hill slopes on exposed rock surfaces, slope base, and landslide toe. Their exposures at the two last locations are perturbed by a blanket of thick soils making their field distinction challenging. The major fracture zone trending ENE-WSW (1500 mm wide) with an inclined dip of 62 degree, extends from the landslide bulge (formed by accumulated debris), down to the foot of adjacent hill towards the Babadorie valley. It contains displaced rock fragments also mentioned by Sillah et al., (2019) and predates the landslide. Attached to it are numerous extensional cracks (tension gashes in soils, parallel and sub parallel with the main lineament), with variable trends and width $(102 \mathrm{~mm}$ to $155 \mathrm{~mm})$ formed by tension stresses and aggravated by the slide movements (Fig. 5).

Insert Figure 5 here.

\subsubsection{Geomorphology}

The major geomorphological elements considered here for comparison include: elevation, slope angle, and slope aspect. The elevations of the slopes affected by Charlotte (CH), Regent (RT) and Madina (MD) landslides are 270, 470 and meters 200 above sea level respectively, and these values were deduced from field works and Digital Elevation Model (DEM) of the area (Fig. 6). They all have steep, but variable slopes at their epicenters and different slope aspects: Charlotte landslide affected Northeast slope face and has a slope angle of 45 degree; slope gradient for Regent landslide is $\approx 60$ degree with a north facing slope; and Madina landslide occurred on a south-west facing slope, with a steep gradient of about 54 degree. The slope value obtained above at Madina depletion zone was validated by the slope result obtained from Orthomosaic analysis, which was done by Track Your Build (TYB). The analysis established the reliability of the clinometer built in the Silva-type compass for slope angle determination. These slope angles for all three landslides reduce towards the lower part of the slides (toes) on both flanks.

Insert Figure 6 here.

In addition to the above, schematic cross-sections drawn revealed visual morphological understanding of each of the landslides. Included into the schematic diagrams are the geology and tectonic signatures of 
the various landslides. The cross-section of Regent landslide is an updated / modified pre-existing crosssection of Regent landslide done by Redshaw et al. and Lahai and Lahai, 2019. (Fig. 7)

Insert Figure 7 here.

Insert Figure 8 here.

Insert Figure 9 here.

\subsection{Conclusions And Recommendations}

\subsection{Conclusions}

Landslide characteristics constitute the required data needed to produce a landslide susceptibility map, necessary for engineering designs and an overall disaster management. This work has presented an understanding of the geology, tectonic (structural geology) and geomorphological characteristics of the three landslides. Therefore, the undermentioned could be concluded from the work.

The rock types played a major role in the rainfall-triggered landslides, as they underwent intensive weathering to form thick soil profiles observed at landslide ridges and flanks/head walls. The compositional variation of the underlying landslide rocks did not entirely influence distinct weathering pattern. For instance, there is a notable difference in the thicknesses at the ridge tops of Regent and Madina landslides despite having the same composition. Also, Charlotte has a thicker flank than the flanks of the other two landslides mentioned above despite its lesser mafic composition compared to the other two landslides (mafic silicates like olivine and pyroxene tend to weather much faster than felsic minerals (quartz and feldspars) www.uh.edu>weath). Soil thickness and weathering pattern here could be strongly correlated to bedrock texture, geochemistry, mechanical discontinuities (joints, faults and shears) and the degree/depth of laterization and saprolite development as observed by Redshaw et al., 2019.

The lineaments on the landslide bodies and surroundings correspond to regional trends in Fig. 1 (Right). Landslide margins and failure patterns are under great influence of the localized lineament pattern of each landslide area. They vary from one landslide to the other in terms of their density, nature and characteristics, indicating different structural geological conditions. Unlike the Madina landslide main scarp (depletion zone), the main scarp of Regent landslide shows dense lineaments, and water seepages draining from the open joints (this is common during the rains), suggesting deep-seated fractures. Similar open fractures with running water on the second bench are also observed on the Charlotte landslide. As noted by Redshaw et al. 2019, the basal controlling discontinuities may have effectively contributed to the formation of benches on Charlotte and Regent Landsides.

The landslides occur on steep lands (Fig. 6). They have steeper angles (> 45 degree) and affected highland areas (greater than $200 \mathrm{~m}$ a.s.l). Both the elevation and slope gradient reduce along the slope, and are also variable along the flanks. Excluding Madina landslide, relatively two wide benches $(11 \mathrm{~m}$ 
and $13 \mathrm{~m}$ in width) were formed at Charlotte landslide and one bench $(15 \mathrm{~m})$ at Regent slide. All the benches are sub-horizontal, creating a planar platform for accumulated boulders and debris.

\subsection{Recommendations}

Further work involving geotechnical drilling and investigation is required to provide deep-seated structural information (deep-seated fractures/cracks, joints and faults), and better characterization of the slope soil/material. This would validate the inferred structural extent in the subsurface; give a clear indication of the failure surface and the threshold for landslide occurrence.

The preparation of landslide susceptibility map of the area, demarcating safe and unsafe zones is crucial in Landslide Disaster Management. This is good for engineering designs and will be a very useful planning tool to be implemented by the Ministry of Lands, Housing and the environment, and also the Freetown City Council.

According to the Global Environmental report in 2017, Sierra Leone is ranked as the third most vulnerable country to the effects of climate change, evident by landslide and flood events every year during the rains. To minimize fatalities from hydro related disaster like landslides, government should utilize funds from development partners, to effectively establish Rain gauge stations at various zones within the Freetown complex, from which variation in rainfall density would be derived. This information will help advice and give early warning to appropriate authorities.

\section{Declarations}

Competing interest (Not applicable here)

Author's contribution (Not applicable here)

Funding (Not applicable- external funding was received. The authors financed the research work)

Availability of data and materials (few data used and /or analyzed during the current study are available from the corresponding author on reasonable request, while others from the country's NMA have restrictions on their availability)

Acknowledgement (Not applicable here)

\section{References}

1. Aleotti P, and Chowdhury R (1999) Landslide hazard assessment: Summary review and new perspectives. Bull Eng Geol Environ, 58:21-44.

2. Al-Nahmi F, Alami OB, Baidder L, Khanbari K, Rhinane H, Hilali A (2016) Using Remote sensing for lineament Extraction in Al Magbrabah area-Hajjah, Yemen. The international Archives of the Photogrammetry, remote sensing and Spatial Information Sciences, volume XLII-2/W1, 2016). $3^{\text {rd }}$ International Geo Advances workshop, 16-17 October 2016, Istanbul, turkey. 
3. Borrelli L, Ferlisi GNS, Peduto D, Nocero SD, Gulla' G (2018) Geology, slow-moving landslides, and damages to building in the verbicaro area (North-western Calabria region, southern Italy). Journal of Maps 14(2), 32-44. Doi:10.1080/17445647.2018.1425164.

4. Broothaerts N, Kissi E, Poesen J, Van Rompaey A, Getahun K, VanRanst E, and Diels J (2012) Spatial pattern, causes and consequences of landslides in the Gilgel Gibe catchment. Elsevier. doi:10.1016/j.catena.2012.05.011

5. Callegaro S, Marzoli A, et al, 2017. Journal of petrology 58,1811-1840. https://doi.org/10.1093/petrology/egx073.

6. Cerri RI, Reis FAGV, Gramani MF, Giordano LC, Zaine JE (2017) Landslide Zonation Hazard: relation between geological structures and landslides occurrence in hilly tropical regions of Brazil. Annals of the Brazilian academy of Sciences. http://dx.doi.org/10.1590/0001-376520170224.

7. Chalokwu Cl (2001) Petrology of the Freetown-Layered Complex, Sierra Leone: Part II Magma Evolution and Crystallization Conditions. Journal of African Earth Sciences, 32, 519-540. https://doi.org/10.1016/S0899-5362.

8. Chalokwu Cl, Armitage AE, Seney PJ, Wurie CA, Bersch M (1995) Petrology of the Freetown Layered Complex, Sierra Leone: part I. Stratigraphy and mineral-chemical evidence for multiple magma injection. International Geology Review, 37, 230-253. https://doi.org/10.1080/00206819509465402.

9. Che VB, Kervyn M, Ernst GGJ, Trefois P, Ayonghe S, Jacobs P, Van Ranst E, Suh SE (2011) Systematic documentation of landslide events in Limbe area (Mt Cameroon): geometry, controlling and triggering factors. Nat. Hazards, 59, 47-74. http://dx.doi.org/10.1007/s11069-011-9738-3.

10. Chigira M, (2006) Geological and geomorphological characteristics of landslides generated by the mid Niigata prefecture earthquake in 2004. Journal of the Japan Society of Engineering Geology. https://doi.org/10.5/10/jjseg.46.115.

11. Cruden D, Varnes DJ, (1996) Landslide Types and Process. In: Turner AK, Schuster RL (eds) Landslides investigation and Mitigation. Special report 247. Transportation Research Board. National Academy of Sciences, Washington DC, pp 36-75.

12. Cui Y, Cheng D, Choi CE, Jin W, Lei Y, Kargel JS (2019) The cost of rapid and haphazard urbanization: lessons learned from the Freetown landslide disaster. Recent Landslide. DOI 10.1007/s10346-01901167-x.

13. Dai FC, Lee C F, Ngai YY (2002) Landslide risk assessment and management: An overview. Eng. Geol. 64,65-87.

14. Delmonaco G, Falconi L, Leoni G, Margottini C, Puglisi C, SpizziChino DL (2006) Multi-Temporal and Quantitative Geomorphological Analysis on the Landslide of Craco village (M118). Springer. DO10.1007/3-540-28680-2_13.

15. Diels J, (2012) Spatial pattern, causes and consequences of landslides in the Gilgel Gibe Catchment. Elsevier. https://doi:10.1016/j.catena.2012.05.011. 
16. FCC (2014) The Environmental Assessment and Evaluation of Natural Disaster Risk and Evaluation of Natural Disaster Risk and Mitigation in Freetown. Urban Planning Project 2011-14, financed by the European Union. Freetown, Freetown City Council (FCC) and the Ministry of Lands, Country planning and the Environment (MLCPE).

17. Guzzetti F, (2000) Landslide fatalities and the evaluation of landslide risk in Italy. Eng. Geo. 58, 89107

18. Hungr O, Evans SG, Bovis MJ, Hutchinson JN (2001) Review of the classification of landslides of the flow type. Environmental and Engineering Geoscience, 7, 221-238.

19. Igwe O, Una CO (2019) Landslide impacts and management in Nanka area, Southeast Nigeria. Geoenvironmental Disasters. Doi.org/10.1186/s40677-1019-0122-z.

20. Jacobs L, Dewitte O, Poesen J, Maes J, Mertens K, Sekajugo J, Kervyn M (2016) Landslide characteristics and spatial distribution in the Rwenzori Mountains, Uganda. Journal of African Earth Sciences. http://dx.doi.org/10.1016/j.jafrearsci2016.05.013.

21. Jha M, Chowdhury A, Chowdary V, Peiffer S (2007) Groundwater Management and development by integrated remote sensing and Geographic Information Systems: Prospects and constraints. Water Resources Management. Do-10.1007/s11269-006-9024-4.

22. Knapen A, Kitutu MG, Poesen J, Breugelmans W, Deckers J, Muwanga A (2006) Landslides in a densely populated county at the foot slopes of Mount Elgon (Uganda): characteristics and causal factors. Geomorphology 73, 149-165.

23. Kumar K, Jangpangi L, Gangopadhyay S (2014) Highway vs landslides and their consequencies in Himalaya. In landslide Science for a safer Geoenvironment; Sassa, K., Canuti, P., You, Y., Ed's.; Springer: Berlin/Heidelberg, Germany. Pp. 389-395.

24. Lahai YA, Lahai PS Jr (2019) Geological Context and Statistical assessment of the impacts of Sugarloaf Twin Disasters, in Western Sierra Leone. Journal of Geoscience and Environment Protection, 7,226-247. https://doi.org/10.4236/gep.2019.76017

25. Lattman LH, and Parizek RR (1964) Relationship between fracture traces and the occurrence of ground water in carbonate rocks. Journal of hydrology. (64)90019-8

26. Lupiano V, Rago V, Terranove OG, lovine G (2018) Landslide inventory and main geomorphological features affecting slope stability in the Picentino river basin (Campania southern Italy). Journal of maps. https://doi.org/10.1080/17445647.2018.1563836.

27. Maes J, Kervn M, Hontheim A, Dewitte $O$ Jacobs L, Mertens K, Vanmaercke M, Vranken L, Poesen J (2017) Landslide risk reduction measures: A review of practices and challenges for the tropics. Progress in Physical Geography. Earth and Environment. Pp191-221

28. Maki Mateso JC, Dewitte $O$ (2014) Towards an inventory of landslide processes and the elements at risk on the Rift flanks west of Lake Kivu DRC . Geo-Eco-Trop, Vol. 38, No. 1, pp. 137-154. https://doi.org/10.1177/0309133316689344.

29. Nakano M, Cigira M, Lim C, gajam S (2015) Geomorphological and geological features of the collapsing landslides induced by the 2009 Padang earthquake- $10^{\text {th }}$ Asian |Regional Conference of 
IAEG.

30. Ngeku WM, Mathu EM (1999) The El-Nino-triggered landslides and their socio-economic impact on Kenya. Environmental Geology 46, 1123-1133.

31. Ngeku WM, Nyamai CM, Erima G (2004) The extent and significance of mass movements in Eastern Africa: case studies of some major landslides in Uganda and Kenya. Environmental Geology, 46, 2113-1133.

32. Nugraha H, Dhandhun W, Dipayana GA, Cahyadi A, Mutaqin BW, Larasati A (2015) Geomorphometric characteristics of landslides in the Tinalah Watershed, Menorch Mountains, Yogyakarta, Indonesian, Elsevier. Doi:10.1016/j.proenv.2015.07.068

33. Vipin K, Vikram G, Sundriyal YP (2018) Spatial interrelationhip of landslides, litho-tectonics, and climate regime, Satlug valley, Northwest Himalaya. Wiley online Library-Geological journal. https://doi.org/10.1002/gj.3204.

34. O'Leary DW, Friedman JD, Pohn HA, (1976) Lineaments, linear, lineation-Some proposed new standards for old terms. Geol Soc Am Bull 87:1463-1469.

35. Redshaw P, Boon D, Campbell G, Willis M, Mattai J, Free M, Jordan C, Kemp SJ, Morley A, Thomas M (2019) The 2017 Regent Landslide, Freetown Peninsula, Sierr Leone. Quarterly journal of Engineering Geology and Hydrogeology. https://doi.org/10.1144/qjedh2018-187

36. Sander P, Timothy B, Mathew M, Chesley M (2005) Ground water Exploration Based on lineament Analysis and Reproducibility Tests. https://doi.org/10.1111/j. 1745-6584.1997.t600157.x

37. Schuster RL, Fleming RW (1986) Economic losses and fatalities due to landslides. Environmental. Geoscientists. XXiii

38. Sillah SK, Turay ES, Kargbo YJ, Minah AA, Bangura A, Bao K, Bangura EA, Kamara U, Bangura M, Sesay AM, Williams BK, Lahai YA, Conteh RM (2019) Geological assessment of Landslide site at Madina Hill locality, Mortomeh, Regent. DOI: 10.13140/RG.2.2.35232.53760

39. Skilodimou HD, Bathrellos G, Maroukian H, Gbakipapanastassiou K (2018) Physical and Anthropogenic Factors Related to Landslide Activity in the Northern Peloponnese, Greece. LandMDPI. doi:10.3390/land7030085.

40. Thomas MF (1983) Comtemporary denudation systems and the effects of climate change in the humid tropics-some problems from Sierra Leone. In: Briggs, D.J. \& Waters, R. S. (eds) Studies in Quaternary Geomorphology. Geo Books, Norwich, 195-214.

41. Thomas MF (1994) Geomorphology in the tropics. John Wiley \& Sons Ltd, Chichester.

42. Thomas MF (1998) Landscape sensitivity in the humid tropics: a geomorphological appraisal. In: Maloney, B.K. (ed.) Human Activities and the Tropical Rainforest. Past, present and possible future. Springer-Science Business Media, B V, 17-47.

43. UNDP \& EPA (2017) Technical publication: Analysis of the Causal and Trigger Factors of the August 2017 Landslide Risk management in Freetown, Sierra Leone. Freetown: United Nations Development Programme and Environmental Protection Agency. 
44. Van Den Eeckhaut M, Moeyersons J, Nyssen J, Abraha A, Poesen J, Haile M, Deckers J, (2009) Spatial patterns of old, deep-seated landslides: a case-study in the northern Ethiopia highlands. Geomorphology 105, 239-252.

\section{Figures}

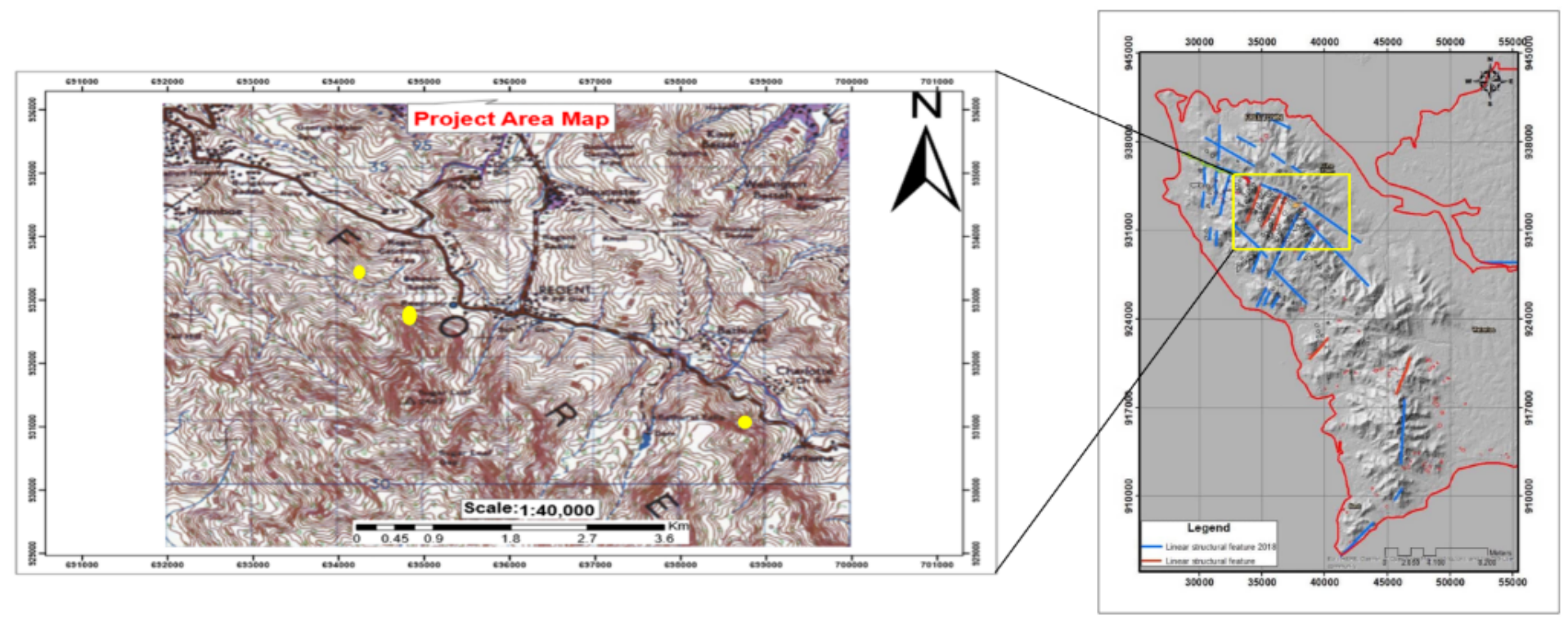

Figure 1

Contour map showing landslide locations (Yellow dots) projected from the Freetown Lineament map (Source: NMA, 2019)

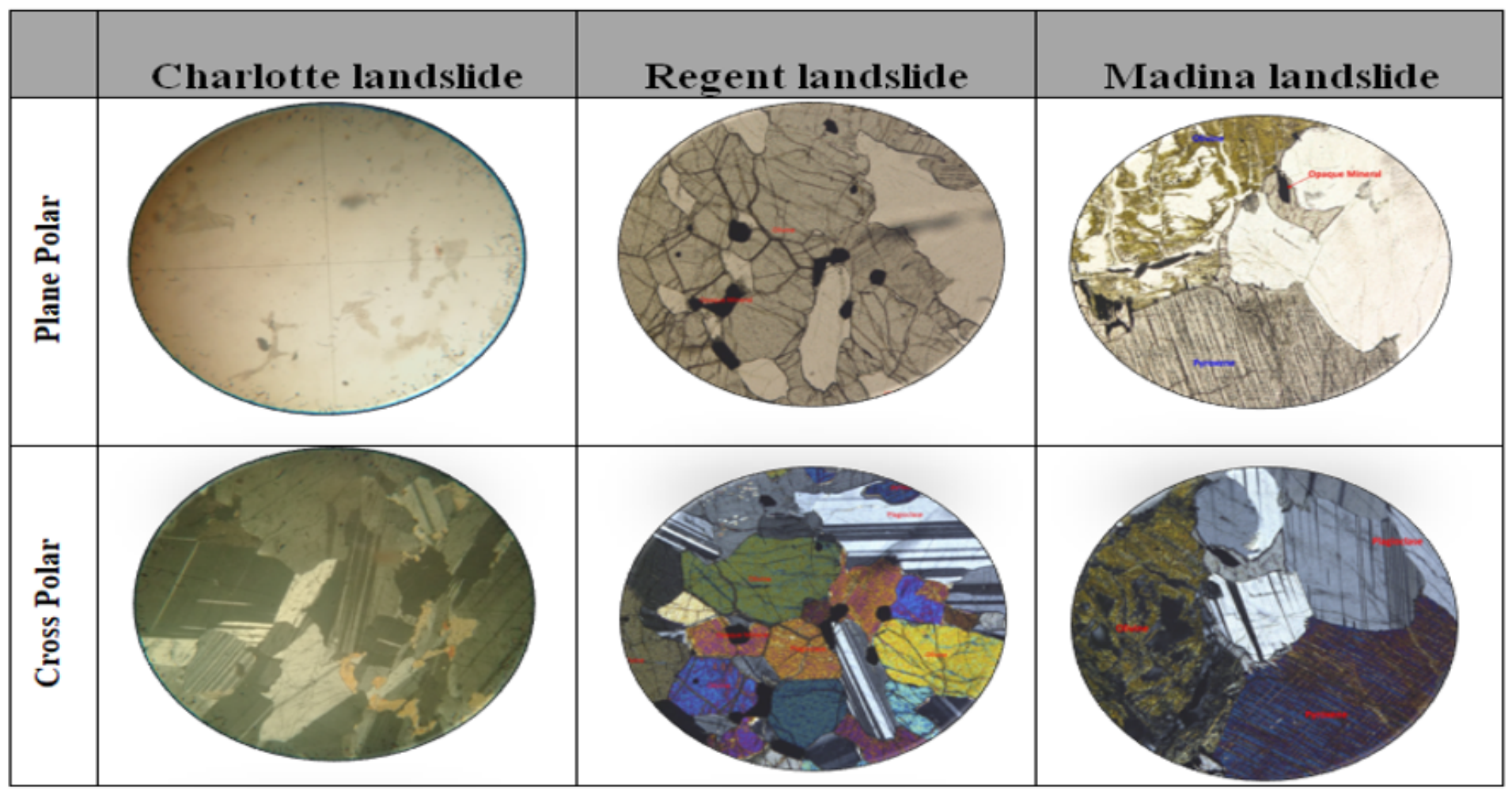


Figure 2

Thin sections of the rock types underlying the landslide areas (Magnification: X4).

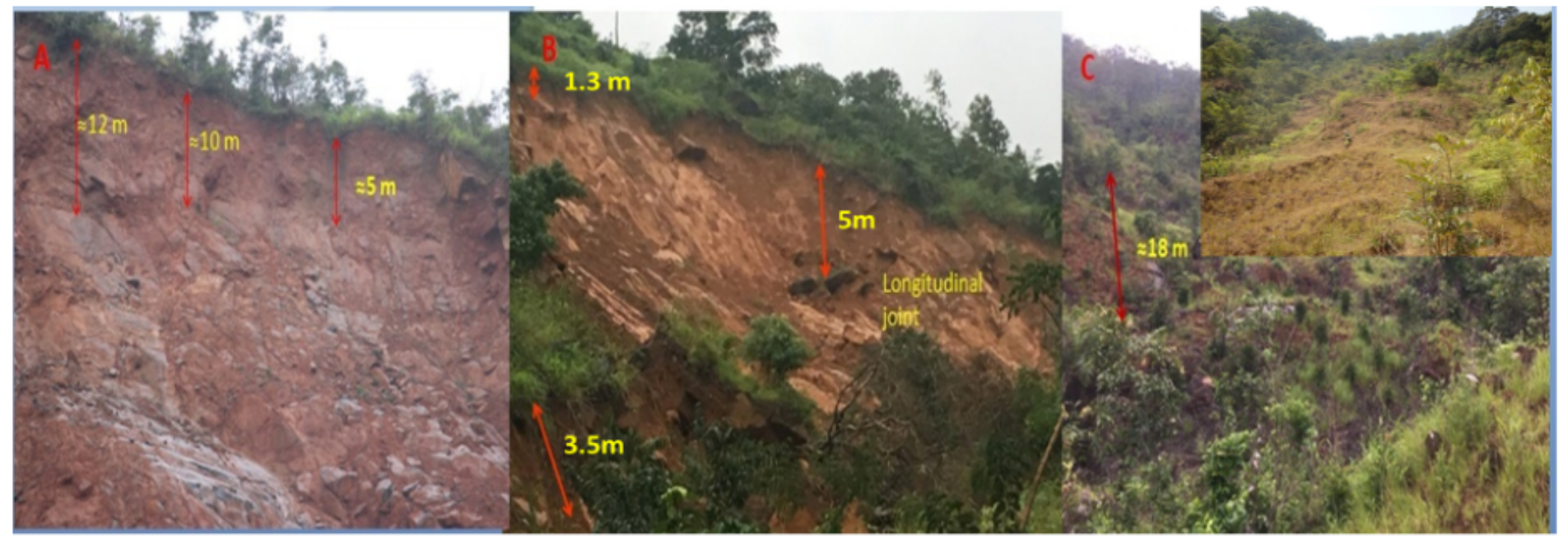

\section{Figure 3}

Weathering profile at landslides' ridges and flanks. (A) Regent landslide; (B) Madina landslide; (c) Charlotte landslide (conditions of upper slope- top right image)

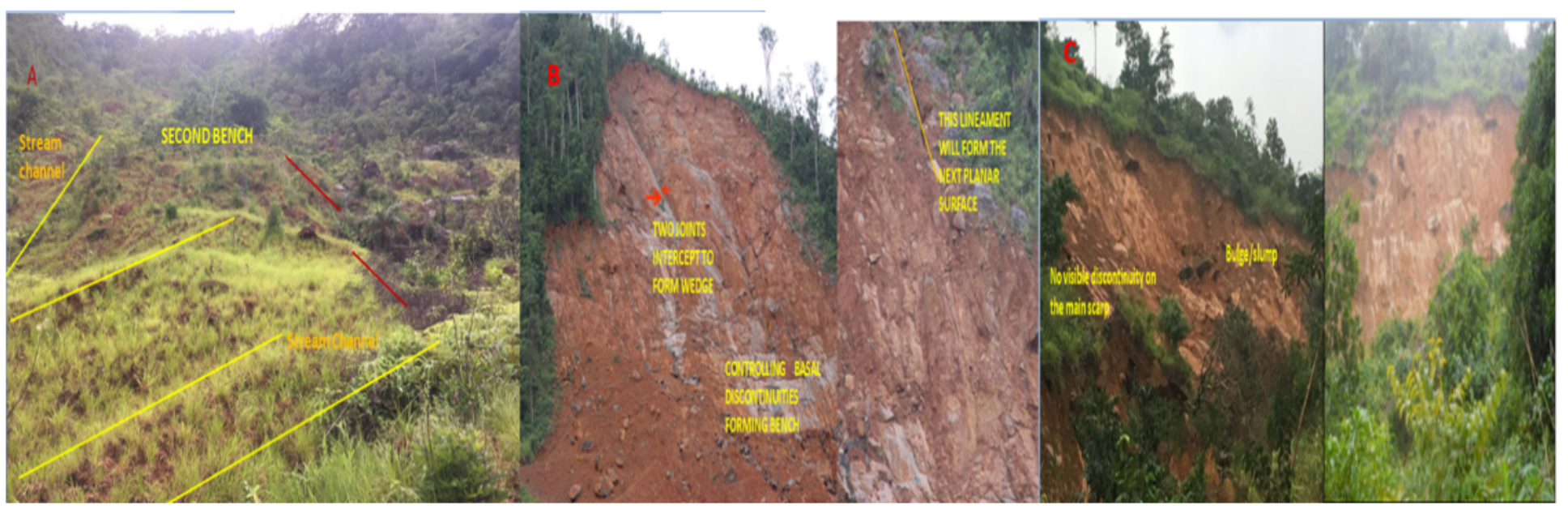

\section{Figure 4}

Discontinuities on the landslide bodies. (A) Charlotte landslide with lineament traces indicated by yellow and red lines (B) Regent Landslide (C) Madina Landslide (no lineament on the main landslide body) 


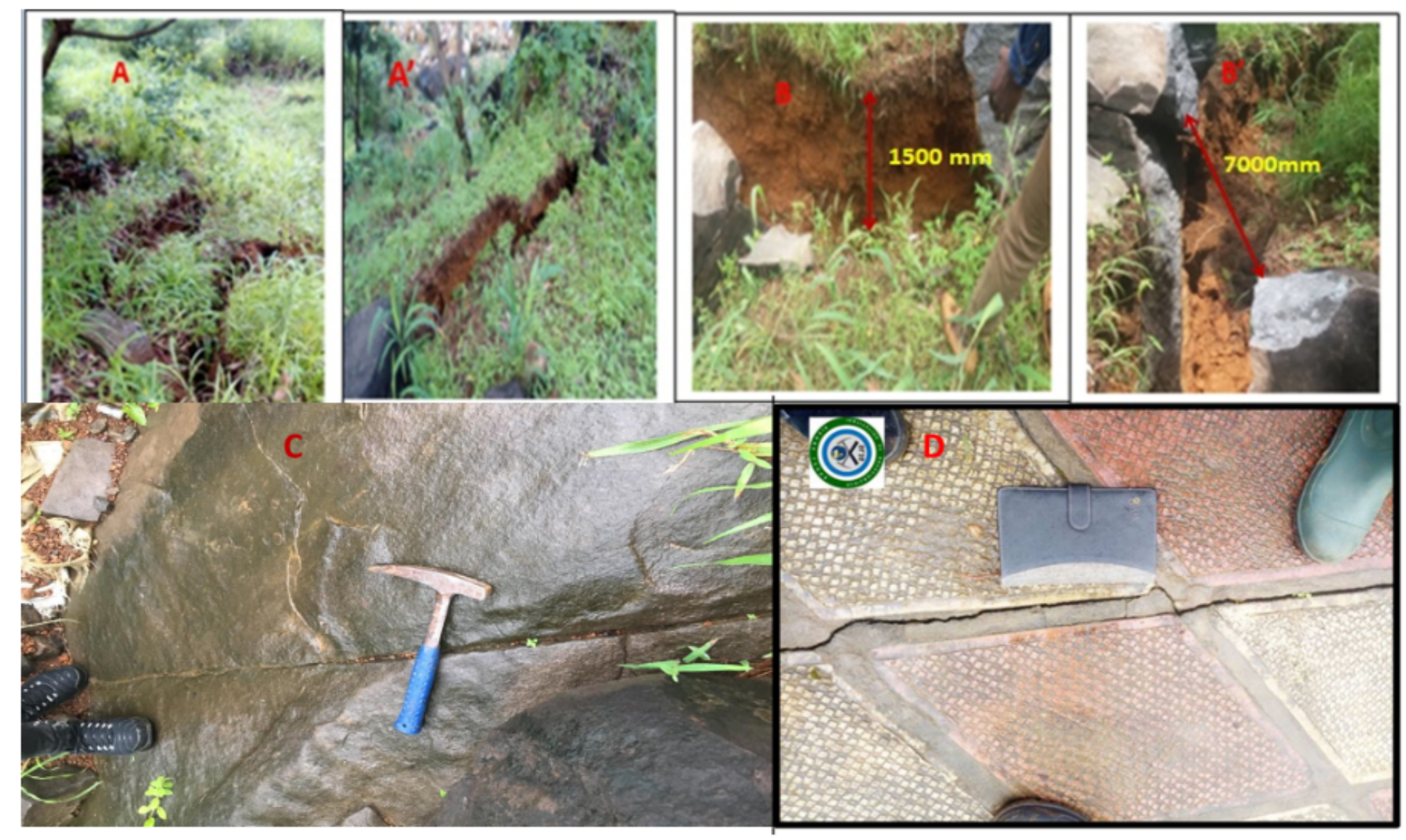

\section{Figure 5}

Lineaments away from the main body of Madina landslide. (A-A') Tension cracks with varying widths in the north west and adjacent to landslide; (B-B') Major fracture zone with displaced rock fragments; (C) Open joint on rock exposure adjacent Madina landslide area; (D) Cracks on the floor of the building-35m away from epicenter of the landslide (Sillah et al., 2019).

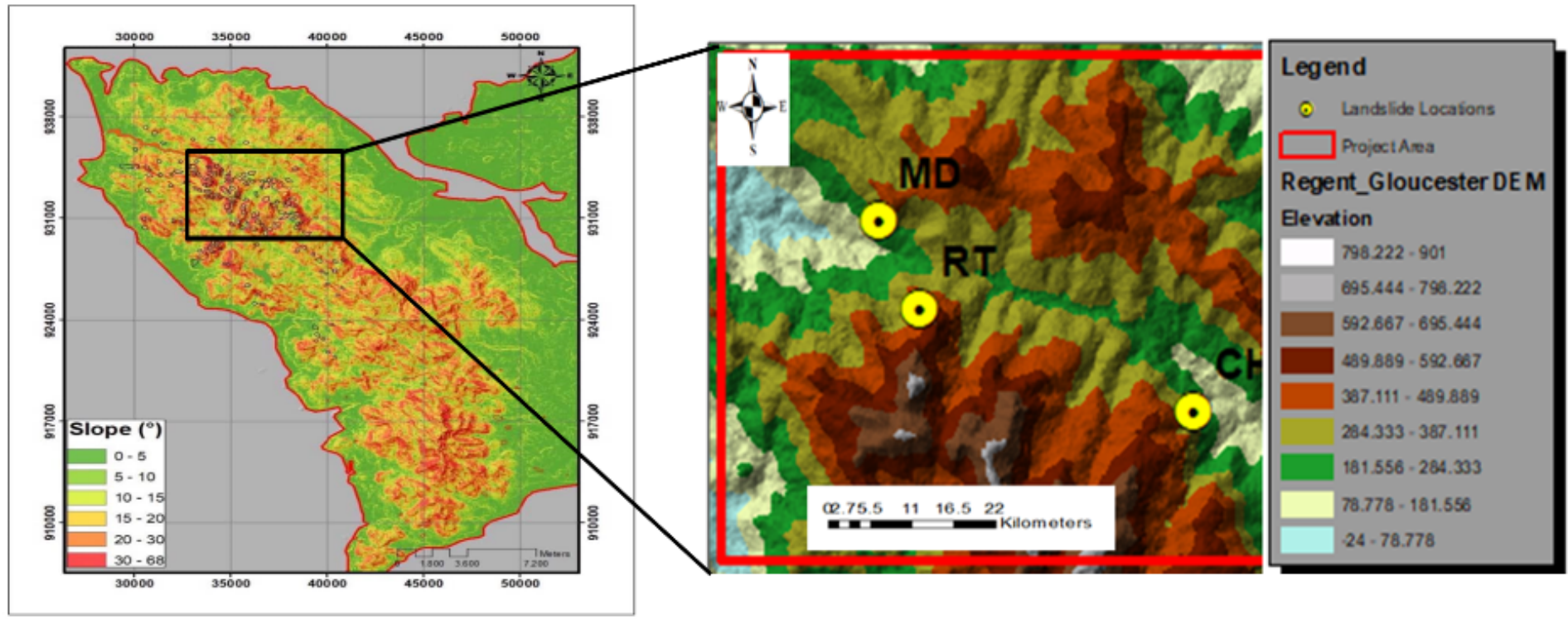

Figure 6 
(A) Regional Slope and landslide historic map of Freetown showing study area (Source: NMA, 2019); (B) DEM of study area projected from figure 6-A-\{Charlotte (CH), Regent (RT) and Madina (MD) landslides\}

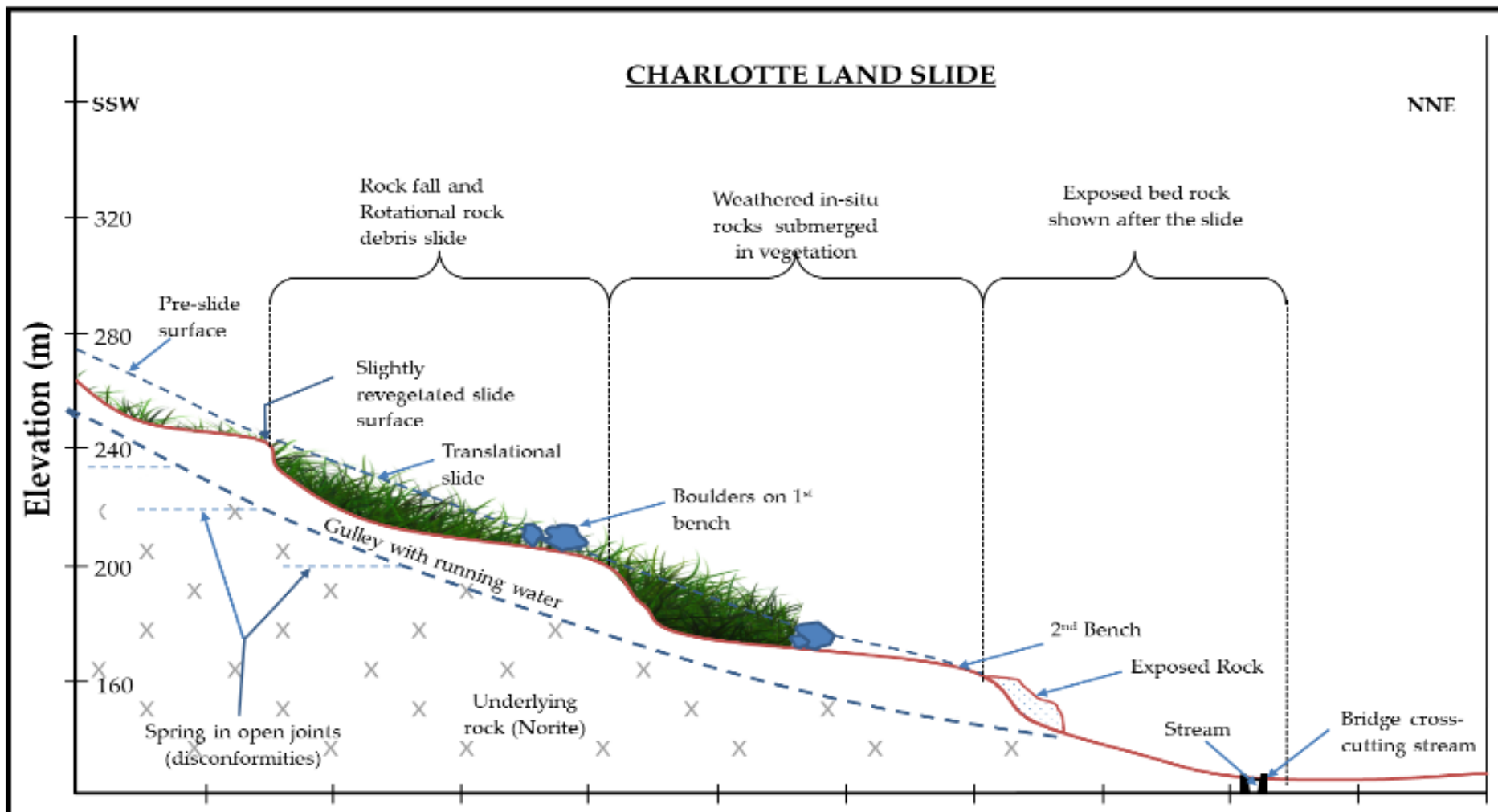

Horizontal distance (m)

Figure 7

Schematic section showing the morphology, lithology and tectonic indicators of Charlotte landslide 


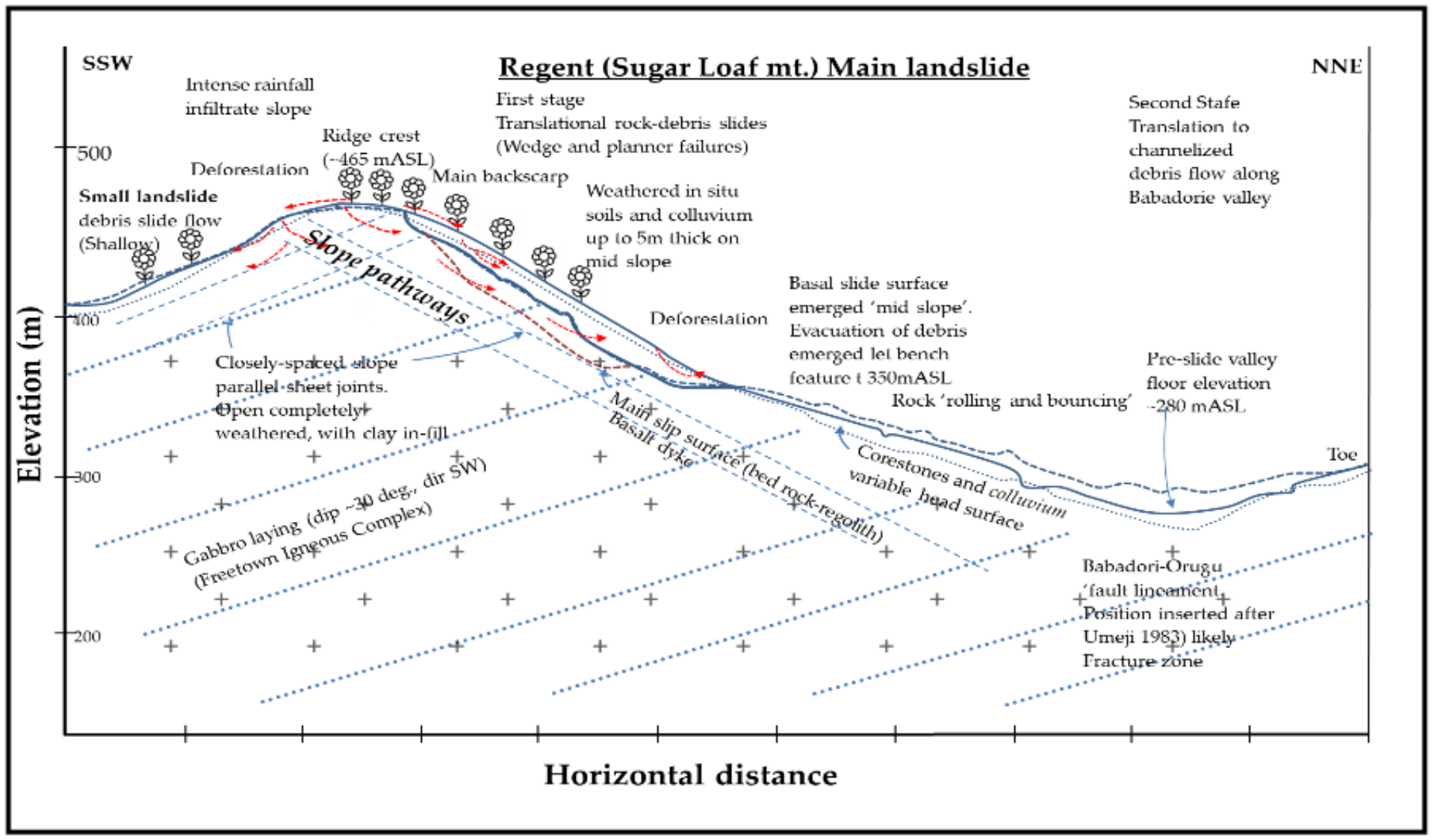

Figure 8

Schematic section of Regent landslide showing GTG features (Modified after Redshaw et al. 2019)

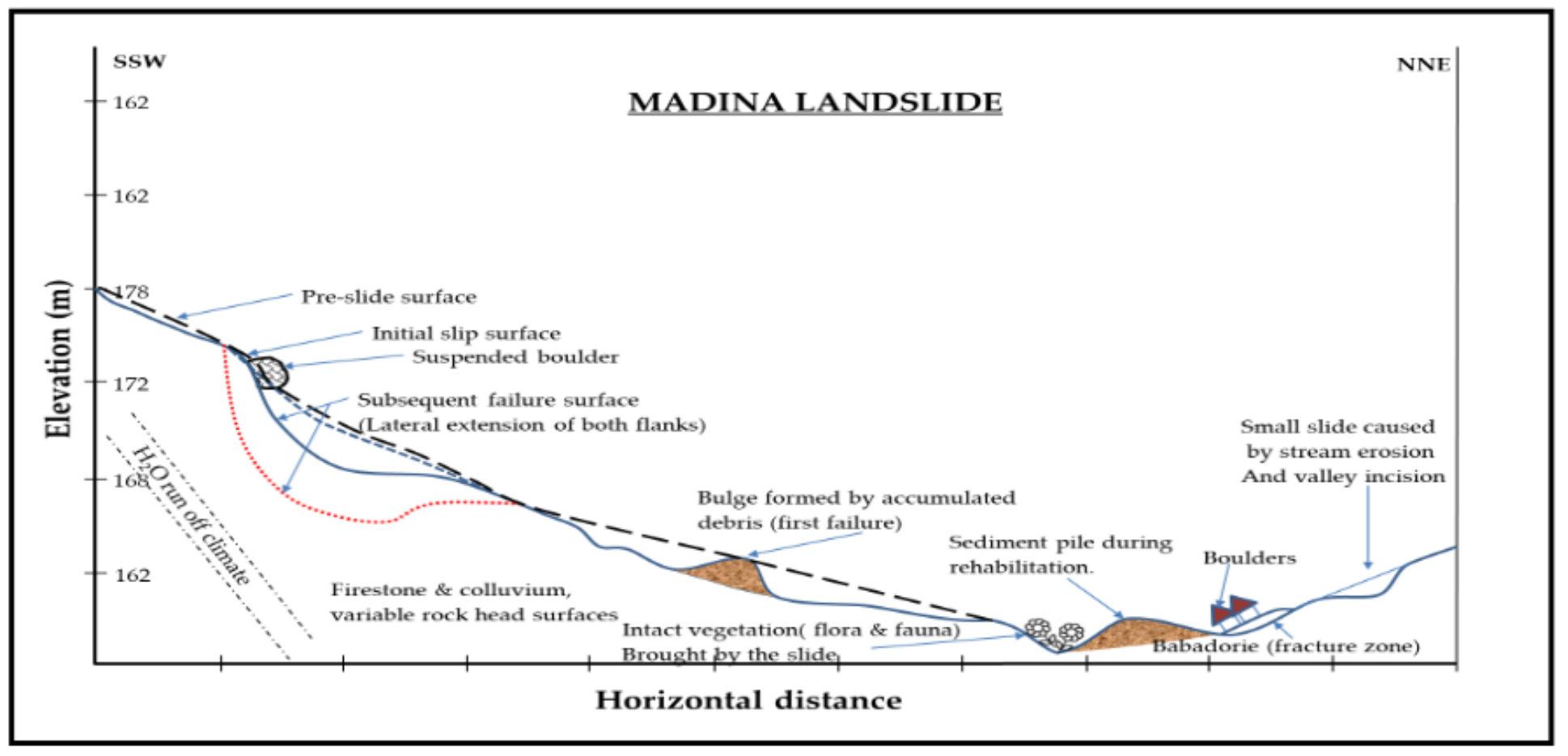

Figure 9 
Schematic cross section depicting the morphology and geology of Madina landslide 